\title{
A mutation in protein kinase C-gamma alters SNC neuron morphology and decreases synaptic vesicles in dopaminergic striatal terminals in the AS/AGU rat
}

\author{
Abdullah Glil Al-Kushi ${ }^{1}$, David Russell ${ }^{2}$, Anthony Philip Payne ${ }^{2 *}$ \\ ${ }^{1}$ College of Medicine, Umm Alqura University, Makkah, Kingdom of Saudi Arabia \\ ${ }^{2}$ School of Life Sciences, Glasgow University, UK \\ Email: *Anthony.Payne@glasgow.ac.uk
}

Received 2 October 2013; revised 5 November 2013; accepted 21 November 2013

Copyright (C) 2013 Abdullah Glil Al-Kushi et al. This is an open access article distributed under the Creative Commons Attribution License, which permits unrestricted use, distribution, and reproduction in any medium, provided the original work is properly cited. In accordance of the Creative Commons Attribution License all Copyrights (C) 2013 are reserved for SCIRP and the owner of the intellectual property Abdullah Glil Al-Kushi et al. All Copyright @ 2013 are guarded by law and by SCIRP as a guardian.

\begin{abstract}
A spontaneous mutation in the Albino Swiss (AS) rat has been shown to be a single point mutation $(\mathrm{ag} u)$ in the gene coding for the gamma isoform of protein kinase C (PKC- $\gamma$ ). The characteristics of the mutant include movement disorders, a failure to release dopamine in the striatum and elevations of molecules such as parkin and ubiquitin in the substantia nigra pars compacta (SNC). This present study examined SNC cell bodies and dopaminergic synaptic terminals within the caudate-putamen. Cell volume and nuclear volume were reduced in the AS/AGU mutant compared to the AS control, but the volume fractions of mitochondria and rough endoplasmic reticulum were significantly higher. No Lewy bodies were present in the mutant, although microglia were found adjacent to some SNC cells. Dopaminergic terminals were identified in the caudate-putamen by electron microscopy with low-glutaraldehyde fixation and immunohistochemistry for tyrosine hydroxylase using immuno-gold visualisation. AS/AGU mutant rats had less than half of the synaptic vesicles of AS controls; this was not only true of "readily-releasable" zones adjacent to the synaptic cleft but also "storage pool" zones. The findings support the hypothesis that the initial bar to dopamine availability in the striatum is the reduced release, with nigral cell death being a later phenomenon.
\end{abstract}

Keywords: PKC-Gamma; Nigral DA Neurons and Terminals; PKC-Gamma; SNC Neurons; Dopaminergic Terminals

"Corresponding author.

\section{INTRODUCTION}

Recently there has been increased interest in the links between neurodegenerative conditions, protein kinases and kinase signaling pathways [1,2] including the protein kinase C (PKC) family [3].

The AS/AGU rat is an Albino Swiss-derived mutant which carries a recessive mutation $(a g u)$ in the gene coding for the gamma isoform of protein kinase C [4]. The rats are characterized by movement impairments including rigidity of the hind limbs, a staggering gait, a tendency to fall over every few step, a slight whole body tremor and difficulty in initiating movements $[5,6]$ and by progressive dysfunction of the nigro-striatal dopaminergic [DA] and raphe-striatal serotonergic (5-HT) systems. The chief defect in both systems is a failure to release transmitter within the striatum under normal physiological conditions. Thus, extracellular dopamine levels in the mutant [measured using microdialysis with HPLC-ECD in conscious animals] are only $10 \%-20 \%$ of control levels [7] and 5-HT is similarly reduced [8]. There is also a marked depletion in utilization of 2-deoxy-glucose in the substantia nigra pars compacta, subthalamic nucleus and ventrolateral thalamus [9]. At later ages, there is a loss of cell bodies within the SNc [5]. There are no cellular inclusions such as Lewy bodies, though some molecules associated with Lewy bodies, such as ubiquitin and parkin, are elevated [10].

It is not clear whether the AS/AGU rat represents a spontaneous useful laboratory model of striatal disorders or an example of accelerated ageing, in which degeneration of neural systems would be anticipated. Nevertheless, the mutant presents an opportunity to examine dopaminergic cell bodies and terminals in a naturally occurring rat model which combines striatal dopamine 
dysfunction with motor disturbance. This study was undertaken to examine the nigral cell bodies and striatal dopaminergic terminals of the mutant and to compare them with control [unaffected] animals. Animals aged twelve months were used, as all mutants are reliably symptomatic at this age.

\section{MATERIALS AND METHODS}

This work was carried out at Glasgow University and has approval from the Ethical Review Process Application Panel; it conforms to the European Community Directive 86/609/EC and the UK Animals [Scientific Procedures] Act [1986].

\subsection{Stereological Examination of Cell Bodies in the Substantia Nigra Pars Compacta}

Five AS control and 5 AS/AGU mutant male rats aged 12 months were used. All rats were killed with carbon dioxide euthanasia and perfused via the left ventricle with mammalian Ringer solution [200 ml] containing the vasodilator Lignocaine followed by $500 \mathrm{ml} \mathrm{3 \%} \mathrm{glutaral-}$ dehyde [Agar-Aldrich Inc, P6148] in $0.1 \mathrm{M}$ phosphate buffer (PB), blood and excess fluid being drained via an incision through the right atrium. The brain was dissected out and immersion-fixed in 3\% glutaraldehyde in $0.1 \mathrm{M}$ of phosphate buffer overnight. Pieces of brain containing areas of interest were serially sectioned at $70 \mu \mathrm{m}$ using a Vibratome (Agar Scientific LTD).

\section{Electron Microscopy}

Midbrains from AS (control) and AS/AGU (mutant) rats were rinsed with $\mathrm{PB}$ and placed in a solution of $1 \%$ osmium tetroxide in $\mathrm{PB}$ for 20 minutes in an agitator. The sections were rinsed with distilled water $(3 \times 30$ mins $)$ and dehydrated through a series of graded concentrations of acetone from $70 \%$ to $100 \%$, followed by a descending ratio of acetone to durcupan resin $(3: 1,1: 1,1: 3)$ and two changes of durcupan resin. The sections were flat-embedded in durcupan resin between two small sheets of acetate, sandwiched between two glass slides, weighted down with metal weights and heated at $60^{\circ} \mathrm{C}$ overnight in an oven. The top acetate sheet were peeled off, stock embedded sections attached onto the end of a blank embedding block using RS adhesive and left for at least 30 min in an oven. The block containing the area of interest was trimmed and semi-thin sections $(1 \mu \mathrm{m})$ cut and stained with $1 \%$ Toluidine Blue buffered to $\mathrm{pH} 8.5$ with sodium borate and examined under the light microscope to confirm the area of the SNC to be thin sectioned and used in stereology. Ultrathin sections (80 - 90 nm thickness) were cut from selected blocks using diamond knives on a Reichert-Jung Ultracut E ultramicrotome. Ultrathin sections were collected on 300 mesh-coated copper grids and double stained with uranyl acetate and lead citrate [11] and examined at a magnification of $5900 \times$ using a transmission electron microscope (JEOL JEM-100S, No. IEM 100S-4, JEOL LTD, Tokyo, Japan). All those SNC cell body profiles containing a nucleolus were photographed and analysed.

The volume fractions (Vv) of mitochondria and rough endoplasmic reticulum were analysed through a random point counting method on 30 SNC cells per animal. A 1 $\mathrm{cm}$ square grid was superimposed randomly on each micrograph three times. The number of grid points that fell on the feature of interest [mitochondria, RER, lipofuscin granules] and the number of grid points that fell on the reference space [cell and cytoplasm] were counted and the $\mathbf{V v}$ were calculated by the Cavalieri principle [12, 13].

\subsection{Examination of Dopaminergic Terminals in the Caudate-Putamen}

It is essential to be able to distinguish dopaminergic terminals within the striatum from other terminals. To do this, we used immunohistochemical labelling of terminals with an antibody to tyrosine hydroxylase followed by secondary labelling with immuno-gold particles $(1 \mathrm{~nm})$ with silver enhancement. To ensure labelling, the fixation regimen used a low percentage of glutaraldehyde consistent with the retention of ultrastructural detail-a mixture of $1 \%$ glutaraldehyde: $4 \%$ paraformaldehyde.

Control procedures included not only confirmation that omission of $\mathrm{TH}$ primary antibody would lead to no gold particles being seen, but also the exclusion of any sections where gold particles could be seen in the lumen of blood vessels. To exclude very peripheral or oblique sections, terminal profiles were only used for analysis if they showed ten or more vesicles and a post-synaptic density.

\section{Measurements of Synaptic Vesicle Numbers}

Synaptic vesicles were counted using a modification of the method of Tao-Cheng [14], (see Figure 1). Two parallel lines were superimposed on the terminal, perpendicular to the synaptic cleft [defined by the post-synaptic density, PSD]. This area was then divided into four zones parallel to the synaptic cleft:

Zones I and II (each $42 \mathrm{~nm}$ wide) contain the two rows of synaptic vesicles immediately adjacent to the presynaptic membrane known as the "readily releasable" pool. Zone III is $84 \mathrm{~nm}$ wide, and contains almost all the remaining vesicles of the reserve pool. Zone IV is up to $134 \mathrm{~nm}$ wide.

The visible length of the synapse (L) on the section was also measured, allowing a calculation of the number of vesicles per synaptic length. A minimum of 10 synapses per animal were analysed. 


\section{RESULTS}

\subsection{SNC Cell Bodies in AS and AS/AGU Rats Aged 12 Months (See Table 1)}

Table 1 shows significant differences between the two groups in relation to the volume of SNC cell bodies and their nuclei. In each case, AS/AGU mutants have smaller cell bodies and nuclei than AS rats of the same age. Regarding cell organelles, the volume density of mitochondria and rough endoplasmic reticulum (either as a fraction of the whole cell body or of the cytoplasm) was raised in mutants. Nuclei often exhibited indented envelopes, but there was no strain difference in the number of indentations. There were no obvious Lewy body inclusions. Many microglial cells were seen near SNC cells in AS/AGU rats (see Figure 2).

\subsection{Synaptic Terminals and Vesicles (See Table 2)}

Low power surveys of the dorsal caudate-putamen showed that AS/AGU mutants possessed significantly fewer TH positive terminals per unit area than AS controls $(23 \pm 2.1$ compared to $43.7 \pm 2 \mathrm{p}<0.01)$. When terminals were analysed at high magnification, AS rats had some $16 \%$ of terminal vesicles in zone I and a similar percentage in zone II, with $42 \%$ in zone III and $26 \%$ in zone IV. This pattern of distribution was similar for AS/AGU rats, although a higher proportion of vesicles were found in zone III (48\%) and a smaller percentage in zone IV (10\%). In all zones, and overall, the number of vesicles was significantly reduced in AS/AGU mutants compared to AS controls.

\section{DISCUSSION}

Two effects of the agu mutation require discussions: 1) the morphology of cell bodies in the SNC and 2) the effects on synaptic terminals within the caudate-putamen. In each case, the results obtained here can be compared with studies on brain ageing, studies on diseases of the nigro-striatal system, and studies involving treatment with toxins to dopaminergic neurons e.g. MPTP or 6OH-DA (for review see [15,16]).

The SNC cell bodies in the parent AS strain resemble existing reports for the rat in consisting of medium-sized neurons with a round, eccentric nucleus, slight nuclear indentations and abundant endoplasmic reticulum [17, 18]. SNC cell bodies were reduced in size in the AS/ AGU mutant strain, as were their nuclei. Cell shrinkage has been reported in animals treated with MPTP [19] or 6-OH-DA [20], as well as in human Parkinson's disease patients [21].

Nuclear indentations are often held to be a characteristic of pathological change $[20,22]$. However, in the pre-

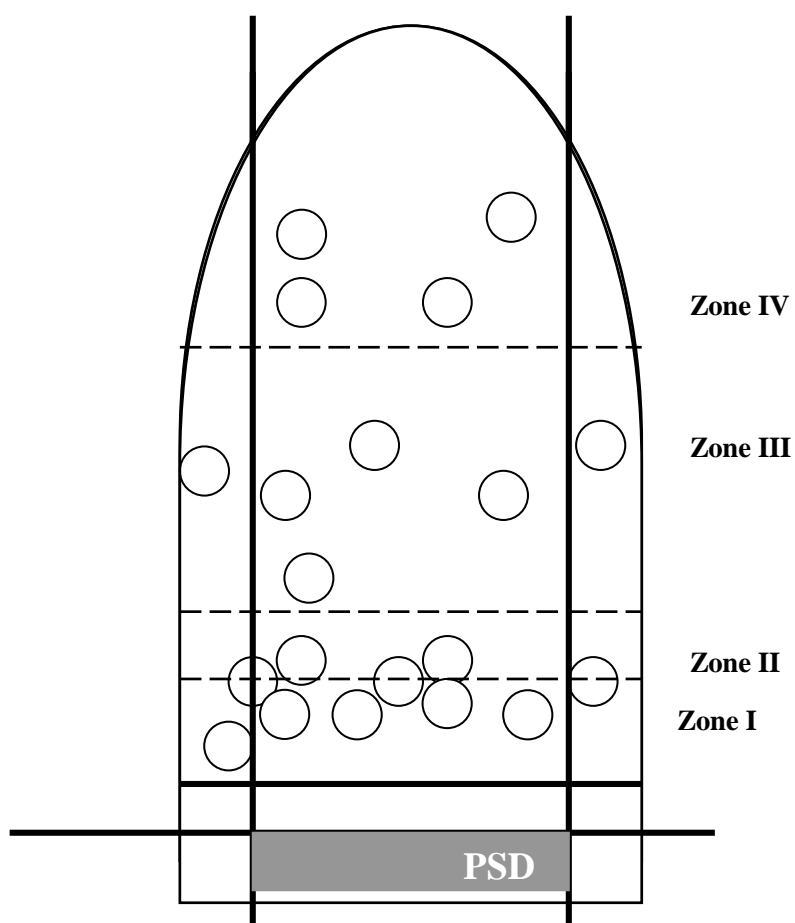

Figure 1. Schematic diagram of synaptic measurement zones. Two parallel lines $(A+B)$ perpendicular to the segment of the presynaptic membrane define the two sides of the area of measurement; the distance between them is the index length $(\mathrm{L})$. Three parallel bands with increasing distance from the presynaptic membrane were marked in dotted lines: Zone I, 0 - 42 nm; Zone II, 42 - 84 nm; Zone III, 84 - $168 \mathrm{~nm}$ and Zone IV, $168-300 \mathrm{~nm}$. The postsynaptic density (PSD) is shown as a dark gray rectangle (modified from Tao-Cheng, 2006).

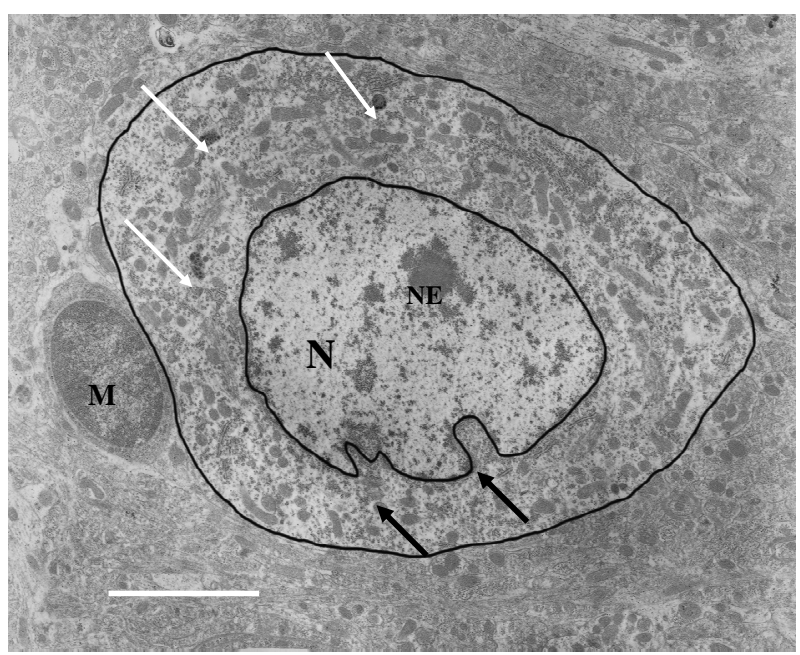

Figure 2. Electron micrograph showing SNC cell in an AS/ AGU [mutant] rat aged 12 months. Black arrows show indented nuclear envelope; white arrow shows lipofuscin deposits; $\mathrm{M}=$ microglial cell; $\mathrm{N}=$ nucleus; $\mathrm{NE}=$ nucleolus $[\mathrm{Bar}=5$ $\mu \mathrm{m}]$.

sent study, both strains showed low, comparable levels of indentation. There was no evidence of chromatin 
Table 1. Volume fraction $[\mathrm{Vv}]$ and volume $[\mathrm{V}]$ of the SNC cell and its organelles in the midbrain of AS control and AS/AGU mutant rats aged 12 months $[n=5$ per group]. All values are mean \pm SEM. All comparisons are two-sample t-tests. RER $=$ rough endoplasmic reticulum.

\begin{tabular}{cccc}
\hline & AS & AS/AGU & p \\
\hline SNC cell volume [V] & $664.1 \pm 25$ & $240.3 \pm 22$ & $<\mathbf{0 0 1}$ \\
SNC nuclear volume [V] & $133 \pm 7.3$ & $53.13 \pm 0.60$ & $<\mathbf{0 . 0 0 1}$ \\
Mitochondrial Vv: [whole cell] & $0.042 \pm 0.002$ & $0.051 \pm 0.002$ & $<\mathbf{0 . 0 5}$ \\
Mitochondrial Vv: [cytoplasm] & $0.082 \pm 0.001$ & $0.089 \pm 0.006$ & $<\mathbf{0 . 0 5}$ \\
RER Vv: [whole cell] & $0.025 \pm 0.0003$ & $0.031 \pm 0.0009$ & $<.05$ \\
RER Vv: [cytoplasm] & $0.046 \pm 0.0023$ & $0.056 \pm 0.011$ & $<\mathbf{0 . 0 5}$ \\
\hline
\end{tabular}

Table 2. Numbers of synaptic vesicles in TH +ve nigrostriatal dopaminergic terminals [identified by immunogold staining for TH] within the DCPU in AS control and AS/AGU mutant rats aged 12 months [ $\mathrm{n}=5$ per group]. All values are mean number of synaptic vesicles $[\mathrm{V}]$ or numbers per synaptic length $[\mathrm{V} / \mathrm{L}] \pm$ SEM. All comparisons are two-sample t-tests [NS: not significant].

\begin{tabular}{|c|c|c|c|c|}
\hline & Terminals & AS & AS/AGU & $\mathbf{p}$ \\
\hline \multirow{2}{*}{$\begin{array}{c}\text { Zone I } \\
\text { [0 - } 42 \text { nm] }\end{array}$} & $\mathbf{V}$ & $9.98 \pm 0.94$ & $5.08 \pm 0.17$ & $<0.05$ \\
\hline & V/L & $36.15 \pm 2.7$ & $14.2 \pm 0.96$ & $<0.05$ \\
\hline \multirow{2}{*}{$\begin{array}{c}\text { Zone II } \\
{[42-84 \text { nm] }}\end{array}$} & $\mathbf{V}$ & $10.11 \pm 0.78$ & $5.57 \pm 0.6$ & $<0.05$ \\
\hline & V/L & $36.61 \pm 1.7$ & $15.64 \pm 2.2$ & $<0.01$ \\
\hline \multirow{2}{*}{$\begin{array}{c}\text { Zone III } \\
\text { [84 - } 168 \text { nm] }\end{array}$} & V & $26.48 \pm 3.3$ & $12.64 \pm 2.6$ & n.s. \\
\hline & $\mathrm{V} / \mathrm{L}$ & $95.7 \pm 9.3$ & $35.7 \pm 8.2$ & $<0.05$ \\
\hline \multirow{2}{*}{$\begin{array}{c}\text { Zone IV } \\
\text { [168 - } 300 \text { nm] }\end{array}$} & $\mathbf{V}$ & $16.63 \pm 2.9$ & $2.72 \pm 0.87$ & $<0.05$ \\
\hline & $\mathrm{V} / \mathrm{L}$ & $60.9 \pm 12$ & $7.76 \pm 2.6$ & $<0.05$ \\
\hline \multirow{2}{*}{ Total } & $\mathbf{V}$ & $63.20 \pm 4.4$ & $26.01 \pm 4.1$ & $<0.01$ \\
\hline & V/L & $229.4 \pm 13$ & $73.3 \pm 14$ & $<0.01$ \\
\hline
\end{tabular}

clumping, such as occurrences in apoptosis following MPTP treatment [23], but this is not surprising since the present study examined a spontaneous neurodegenerative mutant in which the number of apoptotic events at a given time would be few, rather than a model in which widespread cell death had been suddenly provoked by a toxic agent.

The presence of microglial cells near SNC cell bodies is of interest. There is microglial activation in human PD patients [24] as well as MPTP-treated mice [25] and 6-OH-DA-treated rats [26].

It has been shown in a previous study that levels of ubiquitin and parkin are elevated in nigral cell bodies of the AS/AGU mutant compared to the AS parent strain [10]. In idiopathic Parkinson's disease, levels of ubiquitin and parkin (which contains a ubiquitin-like homology domain at its $\mathrm{N}$-terminus and may be involved in the recognition of the substrates and the subsequent degrading of mis-folded proteins) are elevated and the proteins incorporated into cell inclusions [27-30]. Such inclusions have not been found in laboratory models of Parkinson's disease produced through 6-OH-dopamine or MPTP toxicity $[31,32]$ and they do not occur in the AS/AGU mutant rat.
Nevertheless, it is of interest that ubiquitin, parkin and the volume fraction of endoplasmic reticulum are all elevated in the AS/AGU rat compared to the parent AS strain. Parkin expression is induced by ER stress [suggesting an adaptive role in the ER-associated protein degradation pathway to clear misfolded proteins], while overexpression of Parkin suppresses cell death induced by several ER stress-inducing agents. Moreover, Hereditary mutations [33] and the administration of 6-OHDA, MPP and rotenone [34] will all lead to elevated endoplasmic reticulum stress. Coupled with an increase in the volume fraction of endoplasmic reticulum, this suggests that the AS/AGU rat may be dealing with increased levels of mis-folded proteins.

Whole tissue dopamine levels in micropunch samples from the dorsal and lateral caudate-putamen analysed by HPLC-ECD are known to be reduced by some $30 \%$ $40 \%$ in the AS/AGU mutant rat compared to the AS control between 6 and 12 months of age [39]. Similar reductions of dopamine levels in the dorsal striatum have been seen in post-mortem Parkinson's disease patients [35] and in living patients with the disorder [36]. MPTP exposure can also greatly reduce striatal dopamine [37,38]. By contrast, extracellular levels of dopamine in the stria- 
tum as measured in microdialysis samples from conscious, freely-moving AS/AGU rats are reduced by $80 \%$ - 90\% [7]. This leaves the possibility that dopamine is present in striatal terminals in reasonable amounts, but is not releasable under normal physiological conditions. The results obtained in the present study show a considerable reduction in both the number of dopaminergic synaptic terminals per unit area, and in the number of vesicles contained within the remaining terminals. The zonal analysis for synaptic vesicle numbers suggests that the loss is general, is not linked particularly to either the readily-releasable or the storage pool, and is therefore probably not linked to a molecularly characteriseable population of vesicles. In particular, there is no evidence that the region closest to the synaptic cleft is devoid of vesicles. Reduced vesicle counts have been seen in dopaminergic terminals of mice treated with MPTP; low doses caused axon terminals to swell and reduced vesicles; with high doses, terminals disappeared [39]. Paradoxically, in rats treated with 6-OHDA, terminal size and vesicle numbers may increase [40,41] a finding very much at variance with the present study.

The identification of tyrosine hydroxylase positive terminals is a vital element of this study, and there are many potential difficulties associated with labeling for electron microscopy. These include alteration of TH protein by fixation, dehydration and heating leading to decreased recognition by antibodies [42] and high concentrations of glutaraldehyde leading to increased non-specific staining and decreased antigenicity of some proteins [43]. Avidin-biotin-peroxidase labeling may show diffuse artefactual labeling $[44,45]$ and, while immunogoldsilver labeling is more localized, it penetrates less deeply into the tissue [42]. The low level of glutaraldehyde used in our study of terminals was designed to maximize specific immunogold-silver labeling, and, in order to omit obique sections through the periphery of a terminal 1) terminals were considered to be labeled when they contained one or more silver particles which appear as small black aggregates [46] and 2) only labeled terminals showing a post-synaptic density were included. Control procedures included not only confirmation that omission of TH primary antibody would lead to no gold particles being seen, but also the exclusion of any sections where gold particles could be seen in the lumen of blood vessels. The proportion of TH-labeled striatal terminals in AS [control] rats was $17 \%$, a figure consistent with previous studies in rats of $9 \%-21 \%[47,48]$ and man of approximately $16 \%$ [49], suggesting that labeling is dependable.

Given 1) that $\mathrm{TH}$ levels are not depleted in the AS/ AGU mutant [10] and 2) that total dopamine levels within the striatum are less depleted than extracellular levels, one possibility is that dopamine is produced but is not sequestered within vesicles i.e. is free within the cytoplasm. This may explain both the increased striatal levels of extracellular metabolites such as homovanillic acid and DOPAC seen in the mutant [7] and the eventual loss of cell bodies within the SNC $[5,50]$ as dopamine may cause the formation of damaging free radicals or dopaquinones [51,52].

Taken collectively, the investigation of the SNC cell bodies of AS/AGU rats shows a reduction in size of the whole cell and its nucleus, but with an increased volume of cell organelles, suggesting a cell body which is still capable of coping with adverse circumstances and responding to synthetic demands. By contrast, analysis of the dopaminergic terminals within the caudate-putamen reveals a substantial reduction in number plus a substantial reduction in the number of vesicles within those terminals that remain. This could form the basis of both the reduced release of dopamine reported previously and the eventual loss of dopaminergic cell bodies in older animals.

\section{REFERENCES}

[1] Salminen, A., Kaarniranta, K., Haapsalo, A., Soininen, H. and Hiltunen, M. (2011) AMP-activated protein kinase: A potential player in Alzheimer's disease. Journal of Neurochemistry, 118, 460-474. http://dx.doi.org/10.1111/j.1471-4159.2011.07331.x

[2] Wang, G., Pan, J. and Chen, S.-D. (2012) Kinases and kinase signalling pathways: Potential therapeutic targets in Parkinson's disease. Progress in Neurobiology, 98, 207-221. http://dx.doi.org/10.1016/j.pneurobio.2012.06.003

[3] Pascale, A., Amadio, M., Govoni, S. and Battaini, F. (2007) The aging brain, a key target for the future: The protein kinase C involvement. Pharmaceutical Research, 55, 560-569. http://dx.doi.org/10.1016/j.phrs.2007.04.013

[4] Craig, N.J., Duran Alonso, M.B., Hawker, K.L., Shiels, P., Glencorse, T.A., Campbell, J.M., Bennett, N.K., Canham, M., Donald, D., Gardiner, M., Gilmore, D.P., MacDonald, R.J., Maitland, K., McCallion, A.S., Russell, D., Payne, A.P., Sutcliffe, R.G. and Davies, R.W. (2001) A candidate gene for human neurodegenerative disorders: A rat PKC gamma mutation causes a Parkinsonian syndrome. Nature Neuroscience, 4, 1061-1062. http://dx.doi.org/10.1038/nn740

[5] Clarke, D.J. and Payne, A.P. (1994) Neuroanatomical characterization of a new mutant rat with dopamine depletion in the substantia nigra. European Journal of Neuroscience, 6, 885-888. http://dx.doi.org/10.1111/j.1460-9568.1994.tb01000.x

[6] Payne, A.P., Sutcliffe, R.G., Campbell, J.M., Favor, G., Russell, D., Bennett, N.K., Clarke, D.J., Branton, R., Davies, R.W., Simpson, E., Tsang, C. and Baxendale, R.H. (1998) Disordered locomotion in the AS/AGU mutant rat and the effects of L-DOPA or fetal midbrain grafts. Movement Disorders, 13, 832-834. 
http://dx.doi.org/10.1002/mds.870130514

[7] Campbell, J.M., Gilmore, D.P., Russell, D., Growney, C.A., Favor, G., Weir, J., Stone, T.W. and Payne, A.P. (1998) Extracellular levels of dopamine and its metabolite 3,4-dihydroxy-phenylacetic acid measured by microdialysis in the corpus striatum of conscious AS/AGU mutant rats. Neuroscience, 85, 323-325. http://dx.doi.org/10.1016/S0306-4522(98)00053-0

[8] Al-Fayez, M., Russell, D., Wayne Davies, R., Shiels, P., Baker, P.J. and Payne, A.P. (2005) Deficits in the midbrain raphe nuclei and striatum of the AS/AGU rat, a protein kinase C- $\gamma$ mutant. European Journal of Neuroscience, 22, 2792-2798.

http://dx.doi.org/10.1111/j.1460-9568.2005.04502.x

[9] Lam, A.G., Campbell, J.M., Bennett, N.K., Payne, A.P., Davies, R.W., Sutcliffe, R.G. and McCulloch, J. (1998) Local cerebral glucose utilization in the AS/AGU rat: A mutant with movement disorders. European Journal of Neuroscience, 10, 1963-1967. http://dx.doi.org/10.1046/j.1460-9568.1998.00206.x

[10] Al-Kushi, A.G., Russell, D. and Payne, A.P. (2012) Tyrosine hydroxylase and lewy body molecules immunoreactivity in the SNC neurons of an AS/AGU mutant. World Journal of Neuroscience, 2, 150-155. http://dx.doi.org/10.4236/wjns.2012.23023

[11] Reynolds, E.S. (1963) The use of lead citrate at high $\mathrm{pH}$ as an electron-opaque stain in electron microscopy. Journal of Cell Biology, 17, 208-212. http://dx.doi.org/10.1083/jcb.17.1.208

[12] Weibel, E.R. (1979) Stereological methods. Practical methods for biological morphometry. Academic Press, London.

[13] Mayhew, T.M. (1991) The new stereological methods for interpreting functional morphology from slices of cells and organs. Experimental Physiology, 76, 639-665.

[14] Tao-Cheng, J.H. (2006) Activity-related redistribution of presynaptic proteins at the active zone. Neuroscience, $\mathbf{1 4 1}$, $1217-1224$.

http://dx.doi.org/10.1016/j.neuroscience.2006.04.061

[15] Schwarting, R.K.W. and Huston, J.P. (1996) The unilateral 6-hydroxydopamine lesion model in behavioural brain research. Analysis of functional deficits, recovery and treatments. Progress in Neurobiology, 50, 275-331. http://dx.doi.org/10.1016/S0301-0082(96)00040-8

[16] Flint Beal, M. (2001) Experimental models of Parkinson's disease. Nature Reviews Neuroscience, 2, 325-332. http://dx.doi.org/10.1038/35072550

[17] Gulley, R.L. and Wood, R.L. (1971) The fine structure of neurons in the rat substantia nigra. Tissue and Cell, $\mathbf{3}$, 675-690. http://dx.doi.org/10.1016/S0040-8166(71)80013-7

[18] Hajdu, F., Hassler, R. and Bak, I.J. (1973) Electron microscopic study of the substantia nigra and the strio-nigral projection in the rat. Zeitschrift fur Zellforschung und Mikroskopische Anatomie, 146, 207-221. http://dx.doi.org/10.1007/BF00307347

[19] Langston, J.W., Forno, L.S., Rebert, C.S. and Irwin I. (1984) Selective nigral toxicity after systemic administra- tion of 1-methyl-4-phenyl-1,2,5,6-tetrahydropyrine [MPTP] in the squirrel monkey. Brain Research, 292, 390-394. http://dx.doi.org/10.1016/0006-8993(84)90777-7

[20] Choi, W.S., Yoon, S.Y., Oh, T.H., Choi, E.J., O’Malley, K.L. and Oh, Y.J. (1999) Two distinct mechanisms are involved in 6-hydroxydopamine- and $\mathrm{MPP}^{+}$-induced dopaminergic neuronal cell death: Role of caspases, ROS and JNK. Journal of Neuroscience Research, 57, 86-94. http://dx.doi.org/10.1002/(SICI)1097-4547(19990701)57: 1<86::AID-JNR9>3.0.CO;2-E

[21] Anglade, P., Vyas, S., Javoy-Agid, F., Herrero, M.T., Michel, P.P., Marquez, J., Mouatt-Prigent, A., Ruberg, M., Hirsch, E.C. and Agid, Y. (1997) Apoptosis and autophagy in nigral neurons of patients with Parkinson's disease. Histology and Histopathology, 12, 25-31.

[22] Marti, M.J., Saura, J., Burke, R.E., Jackson-Lewis, V., Jimenez, A., Bonastre, M. and Tolosa, E. (2002) Striatal 6-hydroxydopamine induces apoptosis of nigral neurons in the adult rat. Brain Research, 958, 185-191. http://dx.doi.org/10.1016/S0006-8993(02)03694-6

[23] Tanaka, J., Nakamura, H., Honda, S., Takada, K. and Kato, S. (1988) Neuropathological study on 1-methyl-4phenyl-1,2,3,6-tetrahydropyridine of the crab-eating monkey. Acta Neuropathologica [Berl], 75, 370-376. http://dx.doi.org/10.1007/BF00687790

[24] Teismann, P., Tieu, K., Cohen, O., Choi, D.K., Wu, D.C., Marks, D., Vila, M., Jackson-Lewis, V. and Przedborski, S. (2003) Pathogenic role of glial cells in Parkinson's disease. Movement Disorders, 18, 121-129. http://dx.doi.org/10.1002/mds.10332

[25] Kohutnicka, M., Lewandowska, E., Kurkowska-Jastrzebska, I., Czlonkowski, A. and Czlonkowska, A. (1998) Microglial and astrocytic involvement in a murine model of Parkinson's disease induced by 1-methyl-4-phenyl-1,2,3, 6-tetrahydropyridine [MPTP]. Immunopharmacology, 39, 167-180.

http://dx.doi.org/10.1016/S0162-3109(98)00022-8

[26] Rodrigues, R.W., Gomide, V.C. and Chadi, G. (2001) Astroglial and microglial reaction after a partial nigrostriatal degeneration induced by the striatal injection of different doses of 6-hydroxydopamine. International Journal of Neuroscience, 109, 91-126. http://dx.doi.org/10.3109/00207450108986528

[27] Spillantini, M.G., Crowther, R.A., Jakes, R., Cairns, N.J., Lantos, P.L. and Goedert, M. (1998) Filamentous alphasynuclein inclusions link multiple system atrophy with Parkinson's disease and dementia with Lewy bodies. Neuroscience Letters, 251, 205-208. http://dx.doi.org/10.1016/S0304-3940(98)00504-7

[28] Cookson, M.R. (2005) The biochemistry of Parkinson's disease. Annual Review of Biochemistry, 74, 29-52. http://dx.doi.org/10.1146/annurev.biochem.74.082803.13 $\underline{3400}$

[29] Gai, W.P., Yuan, H.X., Li, X.Q., Power, J.T., Blumbergs, P.C. and Jensen, P.H. (2000) In situ and in vitro study of colocalization and segregation of alpha-synuclein, ubiquitin, and lipids in Lewy bodies. Experimental Neurology, 166, 324-333. http://dx.doi.org/10.1006/exnr.2000.7527

[30] McNaught, K.S., Perl, D.P., Brownell, A.L. and Olanow, 
C.W. (2004) Systemic exposure to proteasome inhibitors causes a progressive model of Parkinson's disease. Annals of Neurology, 56, 149-162. http://dx.doi.org/10.1002/ana.20186

[31] Forno, L.S., DeLanney, L.E., Irwin, I. and Langston, J.W. (1993) Similarities and differences between MPTP-induced parkinsonsim and Parkinson's disease. Neuropathologic considerations. Advances in Neurology, 60, 600608.

[32] Dauer, W. and Przedborski, S. (2003) Parkinson's disease: Mechanisms and models. Neuron, 39, 889-909. http://dx.doi.org/10.1016/S0896-6273(03)00568-3

[33] Takahashi, R., Imai, Y., Hattori, N. and Mizuno, Y. (2003) Parkin and endoplasmic reticulum stress. Annals of the New York Academy of Sciences, 991, 101-106. http://dx.doi.org/10.1111/j.1749-6632.2003.tb07467.x

[34] Ryu, E.J., Harding, H.P., Angelastro, J.M., Vitolo, O.V., Ron, D. and Greene, L.A. (2002) Endoplasmic reticulum stress and the unfolded protein response in cellular models of Parkinson's disease. Journal of Neuroscience, 22, 10690-10698.

[35] Campbell, J.M., Payne, A.P., Gilmore, D.P., Byrne, J.E., Russell, D., McGadey, J., Clarke, D.J., Davies, R.W. and Sutcliffe, R.G. (1996) Neostriatal dopamine depletion and locomotor abnormalities due to the Albino Swiss rat agu mutation. Neuroscience Letters, 213, 173-176.

[36] Hornykiewicz, O. (1995) Striatal dopamine in dopa-responsive dystonia: Comparison with idiopathic Parkinson's disease and other dopamine-dependent disorders. In: Segawa, M. and Nomura, Y., Eds., Age-Related Dopamine-Dependent Disorders, Karger, Basel, 101-108.

[37] Leenders, K.L., Salmon, E.P., Tyrrell, P., Perani, D., Brooks, D.J., Sager, H., Jones, T., Marsden, C.D. and Frackowiak, R.S. (1990) The nigrostriatal dopaminergic system assessed in vivo by positron emission tomography in healthy volunteer subjects and patients with Parkinson's disease. Archives of Neurology, 47, 1290-1298. http://dx.doi.org/10.1001/archneur.1990.00530120034007

[38] Moratalla, R., Quinn, B., DeLanney, L.E., Irwin, I., Langston, J.W. and Graybiel, A.M. (1992) Differential vulnerability of primate caudate-putamen and striosomematrix dopamine systems to the neurotoxic effects of 1methyl-4-phenyl-1,2,3,6-tetrahydropyridine. Proceedings of the National Academy of Sciences of the United States of America, 89, 3859-3863. http://dx.doi.org/10.1073/pnas.89.9.3859

[39] Snow, B.J., Vingerhoets, F.J., Langston, J.W., Tetrud, J.W., Sossi, V. and Calne, D.B. (2000) Pattern of dopaminergic loss in the striatum of humans with MPTP induced parkinsonism. Journal of Neurology, Neurosurgery \& Psychiatry, 68, 313-316. http://dx.doi.org/10.1136/jnnp.68.3.313

[40] Cochiolo, J.A., Ehsanian, R. and Bruck, D.K. (2000) Acute ultrastructural effects of MPTP on the nigrostriatal pathway of the C57BL/6 adult mouse: Evidence of compensatory plasticity in nigrostriatal neurons. Journal of Neuroscience Research, 59, 126-135. http://dx.doi.org/10.1002/(SICI)1097-4547(20000101)59: 1<126::AID-JNR15>3.0.CO;2-L
[41] Pickel, V.M., Johnson, E., Carson, M. and Chan, J. (1992) Ultrastructure of spared dopamine terminals in caudateputamen nuclei of adult rats neonatally treated with intranigral 6-hydroxydopamine. Brain Research. Developmental Brain Research, 70, 75-86. http://dx.doi.org/10.1016/0165-3806(92)90105-6

[42] Stanic, D., Parish, C.L., Zhu, W.M., Krstew, E.V., Lawrence, A.J., Drago, J., Finkelstein, D.I. and Horne, M.K. (2003) Changes in function and ultrastructure of striatal dopaminergic terminals that regenerate following partial lesions of the SNpc. Journal of Neurochemistry, 86, 329343. http://dx.doi.org/10.1046/j.1471-4159.2003.01843.x

[43] Chan, J., Aoki, C. and Pickel, V.M. (1990) Optimization of differential immunogold-silver and peroxidase labeling with maintenance of ultrastructure in brain sections before plastic embedding. Journal of Neuroscience Methods, 33, 113-127. http://dx.doi.org/10.1016/0165-0270(90)90015-8

[44] Kosaka, T., Nagatsu, I., Wu, J.Y. and Hama, K. (1986) Use of high concentrations of glutaraldehyde for immunocytochemistry of transmitter-synthesizing enzymes in the central nervous system. Neuroscience, 18, 975-990. http://dx.doi.org/10.1016/0306-4522(86)90112-0

[45] Beier, K. (1992) Light microscopic morphometric analysis of peroxisomes by automatic image analysis: Advantages of immunostaining over the alkaline DAB method. Journal of Histochemistry \& Cytochemistry, 40, 115-121. http://dx.doi.org/10.1177/40.1.1370307

[46] Mengual, E. and Pickel, V.M. (2002) Ultrastructural immunocytochemical localization of the dopamine D2 receptor and tyrosine hydroxylase in the rat ventral pallidum. Synapse, 43, 151-162. http://dx.doi.org/10.1002/syn.10033

[47] Pickel, V.M., Beckley, S.C., Joh, T.H. and Reis, D.J. (1981) Ultrastructural immunocytochemical localization of tyrosine hydroxylase in the neostriatum. Brain Research, 225, 373-385. http://dx.doi.org/10.1016/0006-8993(81)90843-X

[48] Descarries, L., Watkins, K.C., Garcia, S., Bosler, O. and Doucet, G. (1996) Dual character, asynaptic and synaptic, of the dopamine innervation in adult rat neostriatum: A quantitative autoradiographic and immunocytochemical analysis. Journal of Comparative Neurology, 375, 167186.

http://dx.doi.org/10.1002/(SICI)1096-9861(19961111)375 $: 2<167::$ AID-CNE1>3.0.CO;2-0

[49] Kung, L., Force, M., Chute, D.J. and Roberts, R.C. (1998) Immunocytochemical localization of tyrosine hydroxyllase in the human striatum: A postmortem ultrastructural study. Journal of Comparative Neurology, 390, 52-62. http://dx.doi.org/10.1002/(SICI)1096-9861(19980105)39 0:1<52::AID-CNE5>3.0.CO;2-P

[50] Payne, A.P., Campbell, J.M., Russell, D., Favor, G., Sutcliffe, R.G., Bennett, N.K., Davies, R.W. and Stone, T.W. (2000) The AS/AGU rat: A spontaneous model of disruption and degeneration in the nigrostriatal dopaminergic system. Journal of Anatomy, 196, 629-633. http://dx.doi.org/10.1046/j.1469-7580.2000.19640629.x

[51] Hastings, T.G., Lewis, D.A. and Zigmond, M.J. (1996) Reactive dopamine metabolites and neurotoxicity: Impli- 
cations for Parkinson's disease. Advances in Experimental Medicine and Biology, 387, 97-106.

http://dx.doi.org/10.1007/978-1-4757-9480-9_13

[52] Stokes, A.H., Hastings, T.G. and Vrana, K.E. (1999) Сy- totoxic and genotoxic potential of dopamine. Journal of Neuroscience Research, 55, 659-665.

http://dx.doi.org/10.1002/(SICI)1097-4547(19990315)55: 6<659::AID-JNR1>3.0.CO;2-C 